\title{
Anotaciones sobre la escritura de lo político $^{1}$
}

\section{Markus Schultze-Kraft ${ }^{2}$}

Escribir bien sobre lo político es una forma de arte. Hoy, pocos escritores entienden el significado de esta premisa. Constantemente nos enfrentamos a artículos, ensayos, informes y libros mediocres y sesgados que pretenden ser "políticos" y "científicos", pero que en realidad son expresiones de sensacionalismo y confusión ideológica o de falta de conocimiento empírico del autor, y generalmente de perspectiva. Entre los autores del mundo germano parlante que no pertenecen a este gran grupo de malos escritores se encuentra Hans Magnus Enzensberger (ver, por ejemplo, su colección de ensayos Zickzack, Suhrkamp Verlag, Frankfurt, 1997; disponible en español bajo el nombre de Zigzag).

¿Qué tienen él y su escritura de especial? Enzensberger es primero y sobretodo un poeta. Con esto no quiero decir que todos los escritores políticos tienen que ser además poetas -esto sería mucho pedir. No obstante, sí quiero significar que Enzensberger conoce la importancia de la forma. Su pensamiento y escritura política se inscriben y sustentan en una clara estructura de argumentación. Él ejemplifica el desafío esencial y principio de la buena escritura sobre lo político: el significado sin forma carece de significado ( Sinn ohne Form macht keinen Sinn»). El sentido altamente desarrollado de su estilo y estructura, su profundo conocimiento empírico y claridad en lo que concierne a sus premisas y objetivos hacen, de leerlo, una empresa realmente agradable. Entre los escritores ingleses y americanos contemporáneos que están a la altura de este desafío se encuentran, en mi opinión, Eric Hobsbawm y Samuel Huntington -en sus últimos tiempos, en su madurez-, para nombrar sólo dos de creencias políticas opuestas. En 1908, F.M. Cornford de Cambridge escribió un ensayo con el título Microcosmographia Academica. Being a Guide for the Young Academic Politician, uno de los escritos políticos más ingeniosos que jamás haya leído en inglés.

1 Este documento fue traducido del inglés al castellano por Catalina Ararat Ospina, estudiante de séptimo semestre de Ciencia Política de la Universidad Icesi de Cali.

2 Director para América Latina y el Caribe del International Crisis Group. 
Estamos en el negocio de la escritura política -y tenemos que ser mejores en ello que el noventa por ciento de nuestros colegas escritores. El punto clave, lo más importante en la buena escritura sobre lo político es que tiene que ser político. Ahora preguntarán ustedes qué es lo político, asunto al que no puedo responder directamente. El debate sobre lo político es eterno, remonta como mínimo hasta Aristóteles. Algunos autores post-modernos o post-estructuralistas, tal como Ulrich Beck, hablan de la "invención de lo político" (Die Erfindung des Politischen), y ubican en su centro la agencia individual al tiempo que critican la noción de estructura, que es cara para los Marxistas y neo-Marxistas. Otros buscan refugio en la "teoría del discurso" -una amenaza francesa- y otros aún son manifiestamente maquiavélicos de corazón pero disimulan sus posiciones políticas al esconderse en la literatura del realismo político. A pesar de ello, tal vez la mayoría de escritores políticos de hoy son oportunistas, quiénes creen en "lo políticamente correcto" y se casan con un ingenuo amor por la democracia y los derechos humanos, que no hace daño a nadie, pero que tampoco hace bien alguno en este mundo.

En nuestra línea de trabajo tenemos que permanecer libres de las tentaciones implicadas en cualquiera de las aproximaciones mencionadas anteriormente. Nosotros no "hacemos discurso" y tenemos muy buenos conocimientos como para creer que la democracia realmente existe en la mayoría de países en los que trabajamos. Constantemente lidiamos con el corazón del realismo -fuerza y coerción- pero, al mismo tiempo, queremos alejarnos de él y contribuir para que la democracia y la paz -en su verdadero sentido- sean una realidad. Este es nuestro desafío.

Nuestra escritura sobre lo político tiene que ser, en consecuencia, tan clara como los tratados legales, e imaginativa y empíricamente sustentada como los ensayos de Enzensberger, para dar un ejemplo (jdifícil de igualar!). En nuestro campo de trabajo recogemos datos y opiniones. Y todos ellos deben ser doblemente revisados, puestos al revés, vistos desde diferentes ángulos y contextualizados. Cuando se piensa la estructura de nuestros informes debemos ser contrafácticos: ¿qué pasaría si ese elemento no existiera, qué impacto tendría esto en la prevención y resolución de un conflicto dado? Finalmente, si no logramos persuadir a nuestros lectores de la fuerza y solidez de nuestros argumentos, toda nuestra empresa habrá sido un fracaso.

Como escribieron William Strunk Jr. y E. B. White en The elements of style:

Si aquéllos que han estudiado el arte de escribir están de acuerdo en algún punto, es en este: el camino más seguro para atraer y retener la atención del lector es siendo específicos, precisos y concre- 
tos. Los más grandes escritores -Home ro, Dante, Shakespeare- sobresalen en elloz, porque tratan lo particular e informan sobre los detalles que interesan. Sus palabras evocan fotografías (1979).

Estoy completamente de acuerdo. Adelante, disfruten y ¡escriban bien!

Bogotá, 6 de agosto de 2004. 